\title{
A PROPRIEDADE INTELECTUAL NA OMC
}

\author{
Marcelo Dias Varella ${ }^{l}$ \\ marcelo.varella@laposte.net \\ Maria Edelvacy Pinto Marinho ${ }^{2}$ \\ mariaedelvacy@yahoo.com.br
}

\section{RESUMO}

Propriedade intelectual se tornou um dos assuntos mais importantes no direito econômico internacional e nas negociações multilaterais. O foro principal é a Organização Mundial de Comércio. Estados Unidos, Japão, Reino Unido, Alemanha, França e Países Baixos são os mais inovadores em tecnologia. Eles contribuem para que a lei de propriedade intelectual mundial seja um sistema rígido. Assim, eles criam dificuldades para que outros países se tornem capazes de adaptar as tecnologias desses países e as reproduzam para competir em mercados livres.

Palavras-Chaves: Propriedade Intelectual; Organização Mundial do Comércio (OMC); Direito Econômico Internacional

\section{Intellectual Property in WTO}

\begin{abstract}
Intellectual property has become one of the most important subjects in international economic law and multilateral negotiations. The main forum is the World Trade Organization. United States, Japan, United Kingdom, Germany, France and Netherlands are the most innovators on technology. They push the world intellectual property law into a rigid system. Thus, they make difficult for others countries, able to adapt their technologies and reproduce them to compete in free markets.
\end{abstract}

Keywords: Intellectual property; World Trade Organization (WTO); international economic law.

\footnotetext{
${ }^{1}$ Professor dos Cursos de Graduação e do Programa de Mestrado em Direito do UniCEUB. Doutor em Direito pela Universidade de Paris I, Panthéon-Sorbonne. Pesquisador do CNPq.

${ }^{2}$ Maria Edelvacy Pinto Marinho é advogada, mestre em direito, e doutoranda em direito pela Universidade de Paris I, Panthéon-Sorbonne
} 


\section{Considerações Iniciais}

A propriedade intelectual é um dos principais instrumentos entre as disputas multilaterais no âmbito da Organização Mundial do Comércio. Estados Unidos, Japão, Reino Unido, Alemanha, França e Holanda, fortes inovadores de tecnologia tentam de tornar as normas internacionais cada vez mais rígidas. Assim, impedem que outros países, com a capacidade de adaptar novas tecnologias e reproduzi-las possam concorrer em mercados mais livres. Entre os países adaptadores, encontramos grande parte dos demais países industrializados, assim como regiões dos países em desenvolvimento: sudeste brasileiro, região de Buenos Aires, de Istambul, do Cairo, leste da China, Sul da Índia, Norte do México. Os demais países procuram defender seus interesses nas negociações multilaterais, mas, na maioria dos casos, são meros espectadores.

O conceito de propriedade intelectual é apresentado sob dois prismas; um enfatiza a idéia de monopólio ${ }^{3}$, sendo entendido como um direito exclusivo, outro posicionamento reflete a idéia de que se protege os direitos do pensamento, sendo uma concepção mais humanista.. A abrangência dos direitos de propriedade intelectual alcança as obras literárias, artísticas e científicas; as interpretações dos artistas-interpretes, a execução, os fonogramas, as marcas de indústria e comércio, as topografias de circuitos integrados; produtos e processos de fabricação em matéria farmacêutica, biotecnologia e, em alguns países, inclusive seqüências de DNA humano.

A proteção destes direitos imateriais é feita mediante uma concessão de monopólio temporário pelo Estado ao autor ou inventor. Em se tratando de patentes de invenções, este prazo é de vinte anos. Dá-se a garantia que para uso da obra ou invenção, por exemplo, deverá ser feito mediante autorização, garantindo a devida retribuição de modo que os custos sejam recompensados, estimulando, em um último momento, o constante investimento em inovação. Além disso, ao revelar a tecnologia utilizada no invento, o Estado permitiria aos concorrentes que aperfeiçoassem a inovação diminuindo, em tese, o tempo necessário para desenvolvimento de outro produto.

\footnotetext{
${ }^{3}$ os direitos de propriedade intelectual são essencialmente direitos de exclusivo ou de monopólio.... Reservam aos titulares a exclusividade na exploração ao abrigo da concorrência . São freqüentemente qualificados como direitos de propriedade, particularmente nas modalidades de propriedade literária ou artística e propriedade industrial. Mas a qualificação nasceu ao final do séc XVIII e continua a existir com a clara função ideológica, para cobrir a nudez crua do monopólio sob o manto venerável da propriedade. “ p. 40 OLIVEIRA ASCENÇÂO, José de. Direito intelectual exclusivo e liberdade. Revista ABPI nº 59 jul/ago 2002 p. 40-49
} 
A presença do Estado neste caso parece numa primeira análise ser contrária com os fundamentos do Estado liberal. A razão, entretanto, para que a concessão de monopólios seja coerente com o desenvolvimento do liberalismo (não interferência do Estado, livre concorrência) é explicada pela teoria do market failure. Segundo esta, o Estado interferiria no mercado para assegurar o equilíbrio, corrigindo uma falha da livre concorrência. Isso porque a ausência de proteção da propriedade intelectual desestimularia o investimento em pesquisa diante da possibilidade de se copiar livremente. ${ }^{4}$ Neste sistema, o Estado não só concederia o direito exclusivo, mas também deveria fiscalizar o abuso destes direitos impedindo práticas nocivas ao mercado.

Quando se analisa o contexto Norte-Sul, contudo, observa-se o questionamento da eficiência do sistema. Um dos principais argumentos em defesa da propriedade intelectual seria o de servir de estímulo ao investimento em $\mathrm{P} \& \mathrm{D}$, posto que asseguraria a essas empresas o retorno do capital investido ${ }^{5}$. Dessa forma, os participantes entram nas discussões em desigual situação. De um lado os países centrais (do norte) responsáveis por $84 \%$ de toda a pesquisa mundial e de outro os em desenvolvimento ou subdesenvolvidos (do sul) que as utilizam mediante o pagamento de royalites ${ }^{6}$. Diante das desigualdades tecnológicas entre Norte-sul, pode-se apontar três posicionamentos no tocante a relação entre propriedade intelectual e desenvolvimento. Existem os que defendem que os países em desenvolvimento foram prejudicados ao adotar normas de propriedade intelectual já que por não produzirem tecnologia, exportarão divisas para países detentores, alimentando o ciclo de dependência com os países desenvolvidos.. O outro ponto é que as normas de propriedade intelectual seriam um instrumento para o desenvolvimento. ${ }^{7}$ Há também autores advogam que os posicionamentos descritos acima são equivocados porque a propriedade intelectual em si não traria mecanismos de distribuição de renda. ${ }^{8}$

\footnotetext{
${ }^{4}$ BARBOSA, Denis Propriedade intelectual- Da convenção de paris ao patamar do novo milênio. Revista ABPI n 52 Mai/jun 2001. p. 40

${ }^{5}$ CORREA, Carlos. Integrating public health concerns into patent legislation in developing countries. Disponível em: www.southcentrer.org

${ }^{6}$ VARELLA, Marcelo Dias. Direito internacional econômico ambiental. Belo Horizonte: Del Rey, 2004.

7 SHERWOOD, Robert M. Propriedade intelectual e desenvolvimento econômico. São Paulo: Editora Universidade de São Paulo, 1992.

${ }^{8}$ CARVALHO, Nuno Pires de.Palestra: A função social da propriedade intelectual. In $6^{\circ}$ Encontro de propriedade Intelectual e Comercialização de tecnologia. Rio de janeiro, 7,8,9 de julho de 2003.
} 


\section{A inserção da propriedade intelectual na OMC}

A negociação da Propriedade intelectual na OMC consolidada no Trips, representou uma modificação no tratamento internacional da propriedade intelectual . A Convenção de Paris permitia aos países aceitarem ou não o conjunto normativo negociado internacionalmente, deixando a cargo dos países definirem quais setores seria interessante proteger, desde que os nacionais e os estrangeiros tivessem o mesmo tratamento. Países de industrialização tardia como o Japão e a Suíça e até mesmo o Reino Unido utilizaram dessa possibilidade. A CUP ${ }^{9}$ previa uma "ampla liberdade legislativa" ${ }^{10}$. Os princípios basilares da Convenção foram: o tratamento nacional, a prioridade, independência das patentes e a repressão do abuso do direito de patente. ${ }^{11}$ A Convenção de Berna de 1886 que versava sobre obras artísticas e literárias apresentava também como princípio o tratamento nacional.

Apesar da estrutura da propriedade já se encontrar alicerçada, a recusa dos países em desenvolvimento em discutir um tratado complementar a Convenção de Paris quanto a patentes em 1991 em Haia fez com que os países desenvolvidos levassem o tema para o GATT. ${ }^{12}$ Na Rodada de Montreal de 1998 foram analisados os resultados da Rodada do Uruguai. Diante da recusa dos países em desenvolvimento de discutir propriedade intelectual no âmbito do GATT, mas sim na OMPI, onde poderiam fazer uso da flexibilidade da Convenção, os países desenvolvidos afirmaram que a condição para o prosseguimento das negociações era a negociação do TRIPS. Somado a isto, os países detentores de tecnologia afirmaram que na ausência deste Acordo as sanções econômicas unilaterais prosseguiriam contra aqueles que não tivessem legislações adequadas para a proteção da propriedade intelectual. ${ }^{13}$ Como exemplo dessa prática em 1991, o Brasil teve um prejuízo na ordem de US\$ 290 milhões em virtude da sobretaxação de alguns de seus produtos como o suco de laranja e a celulose exportados aos EUA por não ter a época legislação sobre propriedade intelectual considerada adequada..

\footnotetext{
${ }^{9}$ Revisada em 1900 em Bruxelas, em 1911 em Washington, em 1925 em Haia, em 1934 em Londres, em 1958 em Lisboa, em 1967 em Estocolmo, Em 1980 em Genebra e em 1990 em Madri.

${ }^{10}$ BARBOSA, Denis. Propriedade Intelectual: A aplicação do Acordo TRIPS. Rio de Janeiro: Editora Lúmen Júris, 2003. P. 38.

${ }^{11}$ BARBOSA, Denis. Propriedade Intelectual: A aplicação do Acordo TRIPS. Rio de Janeiro: Editora Lúmen Júris, 2003. P. 40

${ }^{12}$ CARVAlHO, Nuno Pires de.Palestra: A função social da propriedade intelectual. In $6^{\circ}$ Encontro de propriedade Intelectual e Comercialização de tecnologia. Rio de janeiro, 7,8,9 de julho de 2003.

${ }^{13}$ CARVAlHO, Nuno Pires de.Palestra: A função social da propriedade intelectual. In $6^{\circ}$ Encontro de propriedade Intelectual e Comercialização de tecnologia. Rio de janeiro, 7,8,9 de julho de 2003. p. 96-104
} 
A escolha do Brasil se explica pelo papel que este ocupava frente aos países do Sul na exclusão de alguns setores de proteção, principalmente a indústria de informática, pelo importante mercado consumidor dos produtos farmacêuticos e pela alta dependência das exportações brasileiras em relação ao mercado norte-americano. Em razão das pressões externas e da Rodada do Uruguai, foi aprovada a lei 9.279/96 sobre propriedade intelectual no Brasil. Da mesma forma, certos países africanos e asiáticos foram pressionados pela União Européia, a exemplo da Turquia e do Egito, e pelos próprios Estados Unidos, conforme as zonas de influência de cada país. Nos países do Sul, consolidou-se a visão de que a inserção de cláusulas de propriedade intelectual em acordos comerciais constituiu meio de coação dos países desenvolvidos sobre os países dependentes de tecnologia.

De fato, os países do Sul não tiveram opção de não aderir ao TRIPS. A sua negociação foi incluída no single undertaking da $\mathrm{OMC}$, ou seja, fazia parte do conjunto obrigatório de acordos a serem aceitos, sem a possibilidade de reservas para o ingresso na OMC. O custo da não adesão do acordo importaria portanto no não ingresso na OMC. Ao analisarem a relação Norte-Sul diversos autores ${ }^{14}$ citam o acordo TRIPS como símbolo das perdas para os países do Sul, que tiveram que arcar com os custos do sistema sem que estes fossem refletidos no desenvolvimento dos países. A possibilidade de não ser alvo de sanções unilaterais foi um fator importante na aceitação do TRIPS.

Atualmente, o caso da sobretaxação de produtos brasileiros, poderia apresentar diferente resultado. A OMC não aceita medidas unilaterais, sem um processo prévio de negociação, podendo ser inclusive um instrumento compensador de desigualdades econômicas, caso os acordos internacionais sejam utilizados de forma inteligente pelos países membros. ${ }^{15}$

\footnotetext{
${ }^{14}$ Ver mais sobre: CORREA, Carlos M. Intellectual property rights, the WTO and developing countries: the TRIPS agreement and policy options. New York: Zed books, 2000, 254p; SEN, Amartya. Pobreza e fome. Um ensaio sobre direitos e privações. Lisboa : Terramar, 1999; SACHS, I Estratégias de transição para o séc. XXI: desenvolvimento e meio ambiente. São Paulo: Nobel,1993 ; STIGLITZ, Joseph E. Políticas de desenvolvimento no mundo da globalização. Seminário organizado pelo BNDES, Desenvolvimento e globalização: perspectivas para as nações. P. 333-356.

${ }_{15}$ As posições da Índia e do próprio Brasil têm mostrado isso, como nos exemplos das decisões recentes favoráveis ao Brasil no Órgão de Solução de Controvérsias da OMC, no tocante ao algodão, do aço (ambos contra os Estados Unidos) e do açúcar (contra a União Européia). A OMC pode e deve ser utilizada para que os direitos e deveres nas negociações comerciais dos países não apliquem critérios claros para ambas as partes e que seu descumprimento seja passível de reparação , minimizando o poder econômico de países mais desenvolvidos.
} 
A finalidade de se regulamentar a propriedade intelectual no âmbito da OMC pode ser delimitada em dois objetivos ${ }^{16}$ : a eliminação de barreiras não tarifárias e a proteção da propriedade privada. Dessa forma, não seria possível que só um Estado arcasse com os custos das pesquisas podendo este ser dividido entre os consumidores mundiais e sendo declarada como propriedade privada, em tese, se estaria evitando o confisco.

Nessa perspectiva, podem ser apontados como fatores que justificavam a necessidade por parte dos países desenvolvidos do estabelecimento do TRIPS : a crescente participação dos produtos com altos investimentos em $\mathrm{P} \& \mathrm{D}$, o desenvolvimento de tecnologias que permitem cópias a baixo custo, o processo de globalização e homogeneização dos mercados, o aumento da parcela de custos em P\&D no custo final dos produtos e a redução do ciclo de vida dos produtos ${ }^{17}$.

Diante do alardeado sucesso do tratamento da propriedade intelectual no que concerne a efetividade das normas propostas, observa-se o questionamento da função da OMPI. A necessidade de um órgão como a OMPI estaria nos objetivos duas instituições . Enquanto a OMC objetiva garantir a propriedade intelectual desde que esta esteja relacionada com o livre comércio, a OMPI advoga uma proteção eficiente da propriedade intelectual. $^{18}$

Dessa forma, a estreita relação entre propriedade intelectual e comércio foi definitivamente firmada com introdução do acordo de propriedade intelectual como acordo constitutivo da OMC . Enquanto os tratados precedentes administrados pela OMPI fixavam normas gerais como a Convenção de Paris, que estabeleceu regras mínimas deixando inclusive a cargo de cada país não proteger por patentes áreas estratégicas para o desenvolvimento do país, o TRIPS não autorizava mais que patentes não fossem concedidas em prol do desenvolvimento. Os argumentos do TRIPS focalizavam entre outros a ofensa à ordem pública e ao meio ambiente. O Tratado de Cooperação em Patentes (PCT), também administrado pela OMPI, avançou na internacionalização dos pedidos de

\footnotetext{
${ }^{16}$ CARVALHO, Nuno Pires de.Palestra: A função social da propriedade intelectual. In $6^{\circ}$ Encontro de propriedade Intelectual e Comercialização de tecnologia. Rio de janeiro, 7,8,9 de julho de 2003. p. 96-104

17 FROTA, Maria Stela Pompeu Brasil. Proteção de Patentes de produtos farmacêuticos: o caso brasileiro. Brasília: FUNAG, 1993. P. 44

${ }^{18}$ CARVALHO, Nuno Pires de.Palestra: A função social da propriedade intelectual. In $6^{\circ}$ Encontro de propriedade Intelectual e Comercialização de tecnologia. Rio de janeiro, 7,8,9 de julho de 2003. p. 96-104
} 
patentes ao possibilitar o depósito internacional e a busca internacional ${ }^{19}$. Esses acordos tiveram como principal contribuição a sedimentação de conceitos de propriedade intelectual bem como a viabilidade do pedido de patente ser depositado internacionalmente. $\mathrm{O}$ mérito do TRIPS estava na possibilidade de fiscalização das aplicações das normas que poderiam ensejar retaliações comerciais autorizadas diante do descumprimento do acordo.

\section{O Acordo sobre Propriedade Intelectual da Organização Mundial do Comércio}

O Acordo TRIPS é um dos três acordos multilaterais que estruturam o Acordo Constitutivo da OMC. A Assinatura dos países nestes Acordos é obrigatória para este ser considerado um Estado-membro. O TRIPS é um tratado-contrato ${ }^{20}$ implicando ao país signatário um comprometimento em promulgar leis que internalizem os padrões mínimos constantes no Acordo. Os Estados devem ter em suas legislações nacionais no mínimo o que o acordo da OMC obriga, mas nada impede que possam prever também formas mais restritivas de direitos de propriedade industrial, ou mesmo novas modalidades de direitos de propriedade, tais como os direitos de propriedade intelectual sui generis, sobre plantas, recursos genéticos ou conhecimentos tradicionais a eles associados ${ }^{21}$. A obediência ou exigência de direitos assegurados pelo Acordo fica condicionada, dessa forma a criação de leis nacionais, não gerando, portanto, direito subjetivo para a esfera privada. ${ }^{22}$

Como parte do Acordo constitutivo da OMC, o TRIPS foi construído tendo como princípios basilares $^{23}$ :

- Os Estados-membros não podem fazer reservas, tendo que integrar a totalidade dos acordos (single undertaking);

- O princípio do tratamento nacional segundo o qual não poderá haver diferenças entre direitos de propriedade intelectual de nacionais e estrangeiros ${ }^{24}$;

\footnotetext{
${ }^{19}$ CHAVANNE, Albert ; BURST, Jean-Jacques. Droit de la propriété industrielle. Paris: Dalloz,1998

${ }^{20}$ BASSO, Maristela . o direito internacional da propriedade intelectual. "O TRIPS é um tratado-contrato, não só devido aos seus aspectos relacionados ao comércio, mas porque através dele, bem como dos demais acordos que compõem a OMC, os Estados-Partes, realizando uma operação jurídica, criaram uma situação jurídica subjetiva." P. 174

${ }^{21}$ Ver PLATIAU e VARELLA (orgs). Diversidade biológica e conhecimentos tradicionais. Coleção Direito Ambiental em Debate. Belo Horizonte: Del Rey, 2004.

${ }^{22}$ BARBOSA, Denis. Uma introdução à propriedade intelectual. Vol 1 P. 87

${ }^{23}$ A identificação dos princípios bem como sua explicação de seu conteúdo é realizada por BASSO, Maristela . o direito internacional da propriedade intelectual. Porto Alegre: livraria do Advogado, 2000.
} 
- O princípio da transparência ${ }^{25}$ que estabelece que os Estados-membros devem tornar público as legislações que confeccionarem sobre a matéria no sentido de garantir possíveis contestações, permitir a fiscalização e o acesso à informação por quem tenha direito;

- O princípio da cooperação internacional ${ }^{26}$ que reconhece a necessidade para a efetiva aplicação do Acordo de cooperação técnica e financeira aos países em desenvolvimento seja nos escritórios de propriedade intelectual, responsáveis pelas análises dos pedidos até mesmo na elaboração de leis;

- O princípio da exaustão ${ }^{27}$ segundo o qual os direitos de propriedade intelectual se esgotam com a primeira venda, não podendo o titular do direito exigir que terceiros lhes solicitem autorização para dispor do produto. Seria nesse sentido uma cláusula favorável ao livre comercio, permitindo em um mercado concentrado certo espaço para a concorrência.

O TRIPS abrange os direitos de propriedade intelectual relativos a direitos do autor e conexos, marcas, indicações geográficas, desenhos, industriais, patentes, topografias de circuitos integrados, proteção de informação confidencial. ${ }^{28} \mathrm{Na}$ proteção dos direitos

\footnotetext{
${ }^{24}$ Art 3.1 do TRIPS : “Cada membro concederá aos nacionais dos demais membros tratamento não menos favorável que o outorgado aos seus próprios nacionais com relação a proteção da propriedade intelectual, salvo as exceções já previstas, respectivamente na Convenção de Paris (1967) da Convenção de Berna (1971), na Convenção de Roma e no Tratado de Propriedade intelectual em matéria de circuitos integrados . No que concerne a artistas-interpretes, produtores de fonogramas, e organizações de radiofusão essa obrigação se aplica apenas aos direitos previstos neste Acordo. Todo membro que faça uso das possibilidades previstas no artigo 6 da Convenção de Berna e no parágrafo 1 b do artigo 16 da Convenção de Roma fará uma notificação de Acordo com aquelas disposições ao Conselho TRIPS.

${ }^{25}$ As leis e regulamentos e as decisões judiciais e administrativas finais de aplicação geral relativa a matéria objeto desse Acordo (existência, abrangência, obtenção, aplicação de normas de proteção e prevenção de abusos de direitos de propriedade intelectual) que forem colocadas em vigor por um Membro serão publicadas ou, quando essa publicação não for conveniente, serão tornadas públicas em um idioma nacional de modo a permitir que governos e titulares de direitos delas tomem conhecimento. Os acordos relativos a matéria objeto desse Acordo que estejam em vigor entre Governo ou uma agência governamental de um outro membro também serão publicados."

${ }^{26}$ Art 67 do TRIPS: “ A fim de facilitar a aplicação do presente Acordo , os países desenvolvidos membros, a pedido, e em termos e condições mutuamente acordadas, prestarão cooperação técnica e financeira aos países em desenvolvimento membros e de menor desenvolvimento relativo membros. Esta cooperação incluirá assistência na elaboração de leis e regulamentos sobre a proteção e aplicação de normas de proteção dos direitos de propriedade intelectual bem como sobre a prevenção de seu abuso, e incluirá apoio ao estabelecimento e fortalecimento dos escritórios e agências nacionais competentes nesses assuntos, inclusive na formação de pessoal."

${ }^{27}$ Art 6 TRIPS "para proposta de solução de controvérsias no marco deste Acordo e sem prejuízo no disposto dos artigos 3 e 4, nada neste Acordo será utilizado para tratar da questão dos direitos de exaustão da propriedade intelectual."

${ }^{28}$ Conforme determina o artigo 1.2 do TRIPS
} 
autorais, reforça a Convenção de Berna, à exceção dos direitos morais, tema em que os Estados Unidos evitaram o aumento da efetividade da Convenção, em para proteger o seu setor cinematográfico ${ }^{29}$. No tocante às Marcas, a Convenção de Paris é fortalecida, excetono tocante as marcas notórias. A proteção que antes era restrita aos bens e serviços similares foi estendida pelo TRIPS àquelas que tenham conexão com os bens e serviços comercializados pela marca. Para tanto além da conexão, é necessário que seja provável que a marca seja prejudicada. ${ }^{30}$.

Uma inovação importante foi a consagração das indicações geográficas ${ }^{31}$, que deixam de ser sistemas locais de proteção para se tornarem um sistema mundialmente reconhecido. As indicações geográficas e denominações de origem foram exigidas pelos países europeus, sobretudo França, Itália, Espanha e Alemanha para a valorização dos seus produtos. As indicações geográficas indicam a procedência do produto, que geralmente tem um vínculo psicológico com a qualidade do mesmo, tais como Azeite de Módena, Doce de Pelotas, Café dos Cerrados de Minas. As denominações de origem se relacionam com a qualidade específica de um produto que somente pode ser obtida em uma região do globo, em função das suas peculiadirdades regioinais, a exemplo do Champagne, produzido em Epernay, na França, e de outros vinhos franceses famosos, como o Bordeau ou o Medoc. A maioria dos países ainda não atingiu os níveis de organização territorial suficientes para a emissão de denominações de origem, que o sistema possibilita. O Brasil tem pouquíssimos registros como a indicações Vale dos Vinhedos e Café dos Cerrados de Minas. De qualquer forma, trata-se de um importante instrumento de valoração da cultura local e de construção de identidades regionais. ${ }^{32}$

Da análise do TRIPS observa-se que o objeto de propriedade intelectual que mais sofreu alterações foi provavelmente o de patentes. Antes da criação de um acordo sobre propriedade intelectual no âmbito da Organização Mundial do Comércio, cada país tinha a opção de conceder ou não patentes para qualquer produto que fosse do seu interesse.

${ }^{29}$ CARVAlHO,Nuno Pires de.Palestra: A função social da propriedade intelectual. In $6^{\circ}$ Encontro de propriedade Intelectual e Comercialização de tecnologia. Rio de janeiro, 7,8,9 de julho de 2003 P. 98

${ }^{30}$ BARBOSA, Denis. BARBOSA, Denis. Propriedade Intelectual: A aplicação do Acordo TRIPS. Rio de Janeiro: Editora Lúmen Júris, 2003.

${ }^{31}$ Art 22.1 "Indicações geográficas são, para efeito desse Acordo, indicações que identifiquem um produto como originário de um território de um Membro, ou região ou localidade deste território, quando determinada qualidade, reputação ou outra característica deste produto seja essencialmente atribuída a sua origem geográfica."

${ }^{32}$ Veja VARELLA, M. (org). Propriedade intelectual e desenvolvimento. No prelo. 
Assim, moldava os direitos de propriedade intelectual conforme a sua necessidade de formulação de políticas públicas, com o objetivo de desenvolver setores industrais específicos. No ramo farmacêutico, havia em torno de 40 países com normas para a proteção de produtos e processos de produção. Com o acordo, este número passou rapidamente para mais de 140 países, criando realmente um sistema normativo mundial com certa efetividade.

A concessão de patentes fica condicionada aos requisitos consagrados na Convenção de Paris e reafirmados no artigo 27.1 do TRIPS “ Sem prejuízo do disposto nos parágrafos 2 e 3 abaixo, qualquer invenção de produto ou de processo, em todos os setores tecnológicos, será patenteável, desde que seja nova, envolva um passo inventivo e seja passível de aplicação industrial." No mesmo artigo fica expresso a obrigação da não discriminação entre patentes concedidas a nacionais ou estrangeiros.

Como na Convenção era possível ao país não conceder patentes a setores ficando a exceção a critério dos Estados-partes, de forma diferente o TRIPS determina quais os casos em que poderá haver exceção. Seria o caso da concessão a patente representar ofensa a ordem pública, ou moralidade, ou seja, uma medida necessária para a proteção à saúde humana, animal ou vegetal e ainda para evitar prejuízos ao meio ambiente. Não se define ao certo o que seja ordem pública e moralidade. Os Estados Unidos defenderam a adoção do conceito d'ordre public que envolve um potencial prejuízo a organização social. Os dois conceitos podem ser adotados livremente pelos países, mas não se pode não conceder uma patente a determinado produto, e permitir a sua comercialização ou a sua produção por um nacional.

Quanto aos setores que se permite o não patenteamento estão os métodos de diagnósticos, terapêuticos e cirúrgicos, plantas e animais. Neste ponto o acordo faz uma ressalva quanto aos microorganismos que devem ser patenteados se cumprirem os requisitos de patenteabilidade e em relação as variedade vegetais que devem ser protegidas se não por patentes que seja por um sistema sui generis como foi o caso da UPOV. No Brasil, como na maioria dos países, aceita-se apenas o patenteamento de microrganismos transgênicos, assim definidos na lei 9.729, caso contrário considera-se que não há invenção, mas uma mera descoberta. 
O referido artigo ainda prevê revisão, razão pela qual se discute nos mandatos negociadores o exposto no 27, 3, b. Em virtude do potencial econômico da biotecnologia, os países desenvolvidos têm tentado restringir as exceções autorizadas permitindo, dessa forma, a patente de seres vivos como já ocorre nas suas legislações nacionais. Contudo, as negociações não têm avançado. Os países em desenvolvimento aceitaram a propriedade intelectual acreditando que receberiam em contrapartida uma diminuição das barreiras ao comércio de produtos agrícolas. Contudo, isto não ocorreu . As negociações em Cancun fracassaram porque a União Européia e os EUA não estavam dispostos a diminuir os subsídios agrícolas a seus nacionais. Como não há essa contrapartida as negociações não prosperaram.

Outro ponto em debate, importante para os países com grande diversidade biológica, é a proteção intelectual dos conhecimentos tradicionais associados aos recursos genéticos. Neste caso, exigem que se realize contratos de divisão dos benefícios da exploração de produtos derivados da sua biodiversidade. $\mathrm{O}$ fundamento jurídico repousa na Convenção sobre a Diversidade Biológica, que reconhece os direitos soberanos dos países sobre seus recursos e indica a necessidade desta repartição de benefícios. Um grande obstáculo é a ignorância dos países com diversidade biológica em saber qual produto farmacêutico, agrícola ou alimentar teve na sua fabricação a utilização de um conhecimento, às vezes de estrutura molecular, derivado de um conhecimento tradicional ou de um organismo vivo do seu território. Exigem, portanto, que o solicitante da patente forneça esta informação no momento do pedido, como um dos critérios para a suficiência descritiva. Neste caso, poderiam vincular a concessão da patente a realização de um contrato de divisão de benefícios. Tal proposta foi defendida pelos países megadiversos, tendo sido apresentada ao Conselho TRIPs por alguns destes países incluindo o Brasil. Seria o primeiro passo para que se pudesse repartir os benefícios dos royalties auferidos com a patente como defende a Convenção de Diversidade Biológica. Contudo, os países centrais como EUA, Japão e a União Européia são contrários porque afirmam que a adoção desta medida importaria na criação de um quarto requisito para concessão de patentes que não está passível de revisão pelo Acordo.

O Acordo assegura a proteção aos desenhos industriais, mas não determina se este deve ser realizado por meio de patentes ou por direitos do autor ou por um sistema sui 
generis que mescle estes dois institutos. Trata-se de uma flexibilidade para que as legislações nacionais prevejam a melhor forma a ser adotada pelo país. Os produtos têxteis, neste caso, tiveram um tratamento especial, sendo resultado do lobby das industrias têxteis italianas. ${ }^{33}$ A prazo mínimo de proteção estabelecido foi de dez anos.

Quanto a topografia de circuitos integrados o Trips reconheceu as disposições do Tratado de Washington de 1989, fazendo com que aqueles que não adeririam tivessem que incorporar esta proteção. A diferença estaria na concessão de licenças compulsórias que deve seguir as determinações feitas em matéria de patentes. Neste sentido fala-se em um Washington-Plus. ${ }^{34}$

De acordo com o artigo 70, os países em desenvolvimento tiveram cinco anos para adotar o acordo a contar da sua entrada em vigor. Os países menos desenvolvidos tiveram dez anos, a partir da sua assinatura. Este tempo não pode ser considerado como suficiente para estes países se tornarem competitivos ou desenvolverem suas indústrias, mas apenas um período para os mesmos se adaptarem e criarem estruturas para dar efetividade às normas internacionais. Certos países, como o Brasil, não usaram desta prerrogativa e adotaram normas de propriedade intelectual logo após a entrada em vigor do TRIPS, sobretudo em função das pressões norte-americanas.

De qualquer modo, durante este período de liberdade dos países do Sul, o Órgão de Solução de Controversas decidiu que os países em desenvolvimento deveriam criar uma mailbox, para receber os pedidos de novas invenções, até que as normas entrassem em vigor em seu território. No caso Índia - proteção conferida pelas patentes sobre produtos farmacêuticos e produtos químicos para a agricultura ${ }^{35}$, o OSC indicou que os pedidos poderiam ser depositados, para serem avaliados posteriormente. Desta forma, evita-se que os produtos caiam em domínio público. Durante este período, a patente está protegida. Após o decurso do prazo, todas estes pedidos de patentes serão analisados e, se concedidos, restarão em vigor até a diferença para o prazo normal de concessão, de vinte anos.

\footnotetext{
33 CARVALHO, Nuno Pires de.Palestra: A função social da propriedade intelectual. In $6^{\circ}$ Encontro de propriedade Intelectual e Comercialização de tecnologia. Rio de janeiro, 7,8,9 de julho de 2003.

34 BASSO, Maristela. Direito internacional da propriedade intelectual. Porto Alegre: Livraria do Advogado.2000 P. 243

${ }^{35}$ WT/DS50/R
} 


\section{Interpretação do TRIPS: pontos divergentes}

A aplicação do Acordo TRIPS tem levantado pontos de interpretação divergentes. Não há consenso quanto a possibilidade de proteção das descobertas, quanto a importação paralela e a prática da bolar exception. O órgão de solução de controvérsias tem sido o responsável por emitir interpretações autorizadas a serem seguidas pelos países.

No caso dos requisitos para concessão de patentes os escritórios de propriedade intelectual do Japão, EUA e países integrantes da União Européia acreditam que a identificação de seqüências de DNA por exemplo, desde que identificada sua função poderia ser objeto de patenteamento. Consideram, portanto, haver neste procedimento um caráter inventivo. Países como o Brasil e a Índia defendem que o exemplo descrito acima se trata de uma mera descoberta, não podendo nesse sentido ser considerado como preenchido os requisitos para patenteamento. Nesse sentido, o TRIPS permitiu essa diversidade, mas ainda não há definição emitida pelo Órgão de solução de controvérsias que indique qual o posicionamento a ser adotado por todos.

Um outro caso ${ }^{36}$ foi referente ao artigo 30 que descreve as exceções aos direitos conferidos : "Os membros poderão conceder exceções limitadas aos direitos exclusivos conferidos pela patente desde que elas não conflitem de forma não razoável com sua exploração normal e não prejudiquem de forma não razoável os interesses legítimos de seu titular, levando em conta os interesses legítimos de terceiros.”

Da análise do painel, Correa depreende que estariam permitidas as importações paralelas, o uso da invenção para uso de pesquisa voltada para o ensino, as experiências realizadas para a comercialização do produto "bolar exception". 37 . O painel foi instaurado pela então Comunidade Européia para analisar a conformidade da norma canadense sobre este último tópico. Um exemplo de produto bolar exception seria o que ocorre com os medicamentos genéricos. Significa que a patente quando estivesse perto de expirar seria liberada para empresas que pudessem fazer os testes e procedimentos adequados para colocar o produto no mercado, não havendo dessa forma, uma extensão do período de "reserva de mercado" concedido pelo Estado. Questionava-se a falta de consentimento do

\footnotetext{
${ }^{36}$ WT/DS114/R

${ }^{37}$ CORREA, Carlos M. Acordo TRIPS: quanta flexibilidade há para implementar os direitos de patente? In Arno Dal Ri Junior e Odete Maria de oliveira(orgs). .Direito internacional econômico: tendências e perspectivas. Unijui : Rio Grande do Sul, 2003. p. 391
} 
titular da patente para tal procedimento, uma vez que esta não havia expirado. O órgão de solução de controvérsias concluiu que as medidas adotadas pelo Canadá no caso da permissão dos testes antes da expiração da patente não eram contrárias ao TRIPS, contudo condenou a formação de estoque de produtos farmacêuticos antes do período de concessão. $^{38}$

A questão da importação paralela está vinculada a aplicação do princípio da exaustão ou esgotamento de direitos. Significa que é permitido importar produtos protegidos desde que este tenha sido colocado no mercado primeiramente pelo titular do direito. Contudo, não havia entre países consenso quanto a permissão da importação paralela pelo TRIPS. A interpretação autorizada foi estabelecida na Declaração de Doha determinando que: "5. d) Com relação ao efeito dos dispositivos do acordo TRIPS sobre o esgotamento dos direitos de propriedade intelectual, deixa-se a cada membro a liberdade de estabelecer seu próprio regime no tocante ao esgotamento sem contestação, com ressalva dos dispositivos sobre o tratamento da nação mais favorecida e do tratamento nacional dos artigos 3 e $4{ }^{\# 39}$ Dessa forma, fica a critério dos países-membros legislarem acerca de como o princípio da exaustão internacional deverá ser tratado.

\section{O Brasil e o TRIPs}

Apesar da continuidade do processo de desenvolvimento 'tecnológico', pode-se afirmar que a revolução Industrial representou um marco no que concerne a produção e assimilação das inovações. A tecnologia, dessa forma, passou a ter um valor de mercado que passava a influenciar na arrecadação e nas relações comerciais entre Estados. Do ponto de vista empresarial, a competição por novos mercados agregava de modo incontestável mais um fator: o domínio tecnológico. Do ponto de vista dos Estados, tratava-se de mais um valor que passaria a influenciar a balança de pagamentos. A política de desenvolvimento tecnológico adotada pelos países foi determinante na posição econômica que hoje ocupam: como produtor ou com comprador. Analisando os posicionamentos adotados pelo Brasil percebe-se a ineficiência das políticas públicas adotadas.

\footnotetext{
${ }^{38}$ CORREA, Carlos M. Acordo TRIPS: quanta flexibilidade há para implementar os direitos de patente? In Arno Dal Ri Junior e Odete Maria de oliveira (org). .Direito internacional econômico: tendências e perspectivas. Unijui : Rio Grande do Sul, 2003.p. 397

${ }^{39}$ Declaração sobre o acordo TRIPS e a saúde pública.
} 
O primeiro ponto a ser analisado parte da incorporação do TRIPS a legislação nacional. Havia um dispositivo no TRIPS que permitia aos países em desenvolvimento, como é o caso do Brasil, a incorporação do Acordo em até 4 anos. ${ }^{40}$ Muito foi discutido no Brasil com a promulgação do Decreto 1355 de 1994 sobre quando este deveria entrar em vigência. O judiciário analisando a questão decidiu que :

“ INPI- Patente- Prazo- Vigência- Aplicação do artigo 33 c/c artigo 70.2 do TRIPS - Acordo sobre Aspectos de Direitos de Propriedade Intelectual Relacionados ao Comércio- Decreto Legislativo $\mathrm{n}^{\circ} 30$, de 15/12/94- Decreto $\mathrm{n}^{\circ}$ 1.355, de 30/12/94. I- OTRIPS Ao aprovar o TRIPS pelo Decreto Legislativo n. $30 / 94$ e promulga-lo pelo decreto $\mathrm{n}^{\circ} 1.355 / 94$, publicado no $\mathrm{DO}$ da união de 31/12/1994. II- O artigo 65, em seus itens 1,2 e 3, do TRIPS, traz uma faculdade ou opção de ser exercida pelo Estado-Membro, havendo necessidade de manifestação prévia para que ele possa valer-se do prazo dilatado ali previsto; IIIA faculdade de postergar a Dara de aplicação do TRIPS deve ser exercida em momento próprio, que, in casu, é o momento em que o Estado-Membro ratifica o Acordo, na forma prevista na Constituição Federal e o insere na sua legislação interna. IV .Ao Aprovar o TRIPS pelo Decreto Legislativo $n^{\circ} 30 / 94$ e promulgalo pelo decreto $\mathrm{n}^{\circ}$ 1.355/94 publicado no DO da união de 31/12/1994, O Brasil deixou de fazer uso do previsto nos artigos 65-1 e 65-2, do referido Acordo, que assegurava a faculdade de dilatar a sua aplicação por um período total de cinco anos. Vê-se, assim, que o Brasil optou por aplicar desde logo o TRIPs, eis que ao incorpora-loa sua ordem jurídica interna não manifestou-se no sentido de postergar sua aplicação; V Não tendo o Brasil exercido a faculdade de postergar sua aplicação, chega-se a conclusão que o TRIPS começou a vigorar no Brasil em $1^{\circ}$ de janeiro de 1995. VI Assiste ao Impetrante, ora Apelado, direito à extensão da validade de sua patente por mais cinco anos. VII Em 1/1/2000 decorreu o prazo de cinco anos, estando em vigor, assim, as disposições do TRIPS. VIII Recurso e remessa necessária Improvidos " 41

A opção política da não utilização do prazo concedido no Acordo pode ser explicada pela pressão norte-americana de uma nova sobretaxação das exportações brasileiras. $\mathrm{O}$ fato trouxe conseqüências graves para o país como : o tempo que deveria ter sido concedido para a reestruturação do INPI, que não estava preparado para o recebimento dos pedidos, além da saída de divisas do país com as remessas de royalties ao exterior por quatro anos que não seriam necessários. Países em desenvolvimento como a Índia fizeram uso do prazo concedido.

\footnotetext{
${ }^{40}$ Art 65.2 "Um país em desenvolvimento membro tem direito a postergar a data de aplicação das disposições do presente Acordo, estabelecidas no parágrafo 1, por um prazo de quatro anos, com exceção dos artigos 3,4 e 5."

${ }^{41}$ Apelação em Mandado de Segurança $n^{\circ}$ 98.02.44769-2 ES Quinta Turma do TRF da $2^{\circ}$ Região por unanimidade, Relator : Dês. Federal Tanyra Vargas., j: 25/4/200.
} 
A pressão exercida sobre o Brasil surtiu os efeitos desejados. Após a assinatura do TRIPS o Brasil já promulgou leis que versam sobre propriedade industrial, lei 9.279/96, Lei de Software (lei n. 9.609/98), Leis de direitos autorais (lei 9.610/98 e a lei de cultivares, lei 9456/96).

Apesar de impedir os Estados-parte de escolherem setores estratégicos para a não concessão de patentes, por exemplo, o Acordo TRIPS permite certa flexibilidade aos países signatários para aplicação destes direitos. É o caso da emissão de licenças compulsórias, que podem ser concedidas em virtude do interesse público, emergência nacional e repressão de abusos da patente ou de poder econômico. O Brasil ao legislar sobre a matéria avançou ao incluir como possibilidade de concessão em razão da ausência de fabricação local. Entretanto, as licenças não têm sido utilizadas pelos países em desenvolvimento como é o caso do Brasil. Uma das razões seria a incapacidade tecnológica destes países para copiar produtos e o receio da abertura de um painel que poderia ensejar uma retaliação comercial.

Em relação ao segundo uso terapêutico, o Acordo TRIPS é omisso. Isto é fica a critério dos Estados determinar se aceitam a concessão de patentes para um produto já protegido, mas que foi descoberto um novo uso terapêutico. As razões para concessão de monopólio nesses casos não se justificariam em relação aos custos, já que não se pode avocar a necessidade de retorno dos investimentos uma vez que estes já foram alcançados com a primeira patente. A legislação brasileira seguindo a tendência do TRIPS não trata especificamente sobre o assunto. Contudo, o INPI tem concedido patentes para uma segunda aplicação terapêutica. Nesse sentido também está concedendo patentes para isômeros óticos, também não obrigatórios pelo TRIPS.

As práticas acima referidas são conseqüências da necessidade de se reestruturar as políticas públicas sobre propriedade intelectual de modo que estas possam refletir os interesse do país.

\section{Considerações finais}

A OMC faz parte juntamente com o FMI e do BIRD do tripé regulador da economia mundial idealizado em Bretton Woods. O papel da OMC seria o de reduzir barreiras ao livre comércio. Neste sentido, em um primeiro momento a incorporação de acordo versando sobre Propriedade intelectual pode, causar certa estranheza já que na ocasião outro foro internacional (OMPI) era responsável pela discussão do tema. 
Contudo, o reconhecimento de direitos de propriedade intelectual é imprescindível numa época em que o capital intelectual constitui grande parte do valor agregado nos produtos tecnológicos. Apesar do tema já ter sido tratado em outros foros próprios que não a OMC, como é o caso da OMPI, foi no seio da OMC que o tema passou a ter mais relevância. A razão para tanto estava nas possibilidades de retaliações comerciais decorrentes do descumprimento das regras estipuladas e de pressão para a elaboração de leis específicas nos países signatários . Nessa perspectiva, a OMC foi responsável pela uniformização de critérios mínimos de proteção e por impedir que países-membros excluíssem os direitos de propriedade intelectual de determinados setores por razões de políticas de incentivos estatais. Consolidou, portanto, esses direitos que necessitavam de uma abrangência internacional para serem eficazes na proibição das cópias não autorizadas.

Entretanto, a necessidade do TRIPS não era consenso entre os países negociadores. O objetivo de se estabelecer uma legislação comum entre os países representou a prevalência dos interesses dos Estados desenvolvidos, uma vez que estes são os responsáveis em grande parte pelas inovações tecnológicas. A obrigação do pagamento de royalties é de fato a garantia de arrecadação para estes países. Observa-se também, o interesse das multinacionais na manutenção de monopólio dessas tecnologias nos diversos mercados. A relação entre propriedade intelectual e monopólio era posta a época como uma necessidade de sobrevivência da inovação em escala industrial.

A adoção do TRIPS pelo Brasil impossibilitou que este adotasse medidas de incentivo a inovação em setores como o farmacêutico. Contudo, não é correto afirmar que a assinatura do Acordo foi o fator determinante da dependência tecnológica do país. Até porque a situação não foi alterada substancialmente. No período que não se concedia patentes para produtos farmacêuticos não existiram medidas de incentivo a pesquisa e investimentos no setor que implicassem no desenvolvimento e consolidação de uma indústria nacional . Outros países utilizaram dessa medida, mas investiram de forma pesada em pesquisa e no fortalecimento da cadeia produtiva para depois estabelecerem normas de propriedade intelectual mais abrangentes. Dessa forma, a permissão da cópia por si só não é capaz de promover a inovação.

O sistema de propriedade intelectual é dotado de mecanismos que visam coibir o uso abusivo destes direitos, contudo o Brasil não tem utilizado destes de forma adequada, 
permitindo conseqüências prejudiciais ao mercado e aos consumidores, como é o caso da licença compulsória, da exigência da fabricação local e da importação paralela. Patentes sobre segundo uso terapêutico, isômeros óticos, e compostos com reivindicações muito amplas conhecidos como "Markush fórmula" não fazem parte das obrigações assumidas no TRIPS mas são concedidas pelo INPI.

\section{Referências}

1. BARBOSA, Denis Borges. Propriedade Intelectual - Da Convenção de Paris ao patamar do novo milênio. Revista da ABPI n 52 - mai/ jun 2001. pág.35-42.

2. BARBOSA, Denis. Propriedade Intelectual: a aplicação do Acordo TRIPS. Rio de janeiro: Lumen Júris, 2003. 286p

3. BARBOSA, Denis. Trips E A Experiência brasileira disponível em: http://denisbarbosa.addr.com/trabalhospi.htm

4. BASSO, Maristela. O direito internacional da propriedade Intelectual. Porto Alegre: Livraria do Advogado, 2000. 328 p

5. CARVALHO, Nuno Pires de. Palestra de Abertura: A função Social da Propriedade. $6^{\circ}$ Encontro de Propriedade Intelectual e Comercialização de Tecnologia. Pág 96104. Rio de Janeiro: 7,8,9 de julho de 2003.

6 CHAVANNE, Albert ; BURST, Jean-Jacques. Droit de la propriété industrielle. Paris: Dalloz,1998

7. CORREA, Carlos M. Acordo TRIPS: Quanta flexibilidade há para implementar os direitos de patente? In Arno Dal Ri Junior e Odete Maria de oliveira. .Direito internacional econômico: tendências e perspectivas. Unijui : Rio Grande do Sul, 2003. 361-424

8. CORREA, Carlos. Integrating public health concerns into patent legislation in developing countries. Disponível em: www.southcentrer.org

9. Di Blasi, Gabriel,; Garcia, mario Soerensen; Mendes, Paulo Parente. A propriedade industrial: os sistemas de marcas, patentes e desenhos industriais analisados a partir da lei 9.279, de 14 de maio de1996.

10. FROTA, Maria Stela Pompeu Brasil.Proteção de patentes de produtos farmacêuticos: o caso brasileiro. Brasília: FUNAG, IRPI, 1993.Pág 55

11. OLIVEIRA ASCENSÃO, José de. Direito Intelectual, Exclusivo e liberdade. Revista da ABPI n ${ }^{\circ}$ 59- Jul/ ago 2002.Págs 40-49

12. OLIVEIRA, Maurício Lopes. Reflexão sobre a atividade inventiva. Revista da ABPI $\mathrm{n}^{\circ} 39-\mathrm{Mar} / \mathrm{abr} 1999$ Págs 23-27

13. REMICHE, B. and H. DESTERBECQ. "Les brevets phamarceutiques dans les Accords du GATT: l'enjeu?. Revue de droit international économique, 1996

14. VARELLA, Marcelo. O Direito internacional econômico ambiental Ed. Del Rey, 2003. 